\title{
Genesis of Competences of Local Government of Federal Subjects in Russia
}

\author{
Igor G. Nikitenko \\ Kazan (Volga region) Federal University, 18 Kremlevskaya str., 420008, Kazan, Russia
}

\section{Doi:10.5901/mjss.2014.v5n24p488}

\begin{abstract}
The basic law of Russia recognizes and guarantees local self-government. Declared that it independently within their authority and is not included in the system of bodies of state power. The legal basis of local self-government is a system of legal norms, on the basis of which it is formed and implemented, including legal norms, which is also contained in the decrees of the President of the Russian Federation and the resolutions of the government of Russia. The article gives a detailed review of the relations arising in the process of formation and realization of powers of the subjects of the Russian Federation in the sphere of regulation of local authorities.
\end{abstract}

Keywords: Local self-government, the subject of the Russian Federation, local authorities, state power.

Local government may exist where it is built as a decision making legal institute, with a representative organ having autonomous budget and power to make local laws and elected directly by local population with the help of secret voting [1].

Taking into account historically complicated genesis of federative relations in Russia, where every new historical period was marked by various political events, we should specify these periods first.

Meanwhile, development of local government in the United States can also be characterized as a historically complicated process. "Some are created by direct state action - through a charter, for example - but most are created because state statutes authorize citizens in a particular geographic area who need or desire local services to form a local unit of government" [2].

It should be taken into account that historical periods may be divided depending on objects and goals of studying specific historical events. Thus, for instance, when analyzing nation-state building in the Russian Soviet Federated Socialistic Republic (hereinafter referred to as RSFSR), historians tend to single out periods beginning from most significant events after the October revolution and to developed socialism. Any period is viewed as a historical epoch characterized by fundamental transformations in social and political life [3].

Political scientists have a different view on division of historical periods. They study the Russian federalism and single out periods according to changes of political course of the ruling elite [4]. When analyzing genesis of the Russian state generally and the Russian federalism in particular, legal scientists prefer to mark out periods when Russian constitutions were adopted [5]. In this respect, we assume that with regard to the Russian history, we should single our periods marked by division of competences in regulating local government between the federal center and federal subjects regarding adoption of the Russian constitution in effect. Using the European Charter of Local Self-Government as a case study, we can find out how legal regulation of the local government is changing [6].

The Fifth All-Russian Congress of Soviets was highlighted by adoption of the Constitution of the RSFSR. Articles $53-60,62$ of the said document were dedicated to the problem of competences of local government. It seems that the constitutional basis was insufficient for defining competences of local governments. From all the norms only Article 62 of the Constitution contained a wording that regional and provincial authorities could enjoy the right to control local councils (i.e. all regional Councils were controlled by regional authorities, while provincial Councils under provincial authorities. The exception was made for city councils that didn't belong to district Councils, etc). Besides, regional and provincial Councils and their Executive Committees were authorized to revoke resolutions of the local Councils, informing the Central Soviet government.

Analysis of constitutional norms allows us to conclude that subjects of the Russian Federation enjoyed a limited scope of competences in regulation of local government. Their functions were restricted to controlling over local authorities and revoking some of the Councils' decisions. Meanwhile, the Federation (represented by its central bodies) had to be informed about all cases when decisions of local Councils could be revoked by provincial Councils, as well decisions of the regional Councils. Besides, as it comes from the analysis of constitutional norms, the Federation 
established norms of representation in the Council congresses at every level of political power [7].

Thus, the first constitutional acts reveal centralizing tendencies in regulating local governments.

This period of improving (by way of centralization) practices in realizing competences at every level of the state power in the RSFSR continued until adoption of the first Constitution of the USSR and then the Constitution of the RSFSR in 1925.

When analyzing this period, we should take into account the fact of creation of the USSR in 1922, which determined further development of legislation relevant regulation of local authorities. Adopted in January 315t, 1924, the Constitution of the USSR completed legal implementation of the USSR as a federal state. The Treaty on the Creation of the USSR from December 31'st 1922 didn't stipulate creation of the Soviet of Socialistic Republics, but nevertheless, it could contain some fundamentals for forming a unified state. Therefore the period of creation of the USSR as a unified state was over after adoption of a new constitution at the beginning of 1924.

As far as the peculiarities of the Constitution of 1924 are concerned, the mentioned document didn't contain chapters or specific articles concerning regulation of local government. These decisions were supposed to be made by the republics. Actually, constitutions of the Union republics contained chapters concerning local Councils, as well as norms on cooperation of local government agencies in the Union republics.

However, building the Soviet state required that the Union of SSR should uniform all issues concerning organization of local government. Establishment of universal fundamentals of legal position of local councils viewed from the perspective of the Union was determined by the necessity to increase their role in nation-state building as well as to neutralize differences in creation, competences and forms of mass work, which did not result from specific conditions of some Union republics.

Analysis of legal acts shows that from the very beginning local government agencies in the USSR were flexible in determining competences of local Councils. In some cases, taking into account the necessity of uniformity in solving electoral, financial and other issues, the Union regulated some local governments by issuing associated legal acts. In other cases the Union could be restricted to adoption of similar or general provisions worked out with the help of representatives of the Union republics. These exemplary acts of advisory character made basis for preparing and adopting relevant laws in the Union republics and their subjects [8].

Laws of the Union contained fundamentals concerning the role of the Union in local governments. They stipulated local Councils as supreme authority, enabling them to deal with local matters as well as participate in discussion of regional, provincial, republic and all Union matters. The USSR not only erected this fundamental principle, but determined sharply all competences of the local Councils in regions where they reflected tendencies throughout the Union, i.e. they participated in governing fields under jurisdiction of the Union or Union and republics. For instance, this refers to articles concerning competences of the Councils in strengthening the defense capability, taxation, state statistics, etc.

Analysis of some other normative acts of the USSR concerning issues of building the Soviet state prove that the Soviet law maker tended to centralization. These tendencies are very vivid not only in normative acts, but the competences of local Councils in social and cultural development, but in acts of organization and mass work of these Councils.

The Union government agencies adopted acts concerning relations between the local authorities and supreme Soviet authorities, and correspondingly set goals for Central Electoral Commissions of the Union and autonomous republics, formed the structure of executive committees of the local Councils.

Legal regulation of local authorities in corresponding period witnessed increase of centralistic tendencies. As has been pointed out in legal literature, increase of "centralization was historically determined by the necessity of uniting all political and economic efforts to find solutions to socialistic reconstruction as well as by the class war that took place during socialistic transformation of the country".

The said period marked by development of competences of subjects of the Russian Federation in regulating local government was over after the adoption of the Constitution of the USSR in 1936 and the Constitution of the RSFSR in 1937.

The Constitution of the USSR from December $5^{\text {th }}, 1936$ was of the same centralistic tradition as its predecessor. For the first time ever a constitution (Chapter VIII) was dedicated to local governments. This Chapter determined fundamentals of the national legislation concerning local Councils including their system, way of forming and term of tenure, basic competences, types of legal acts, executive boards and their relations with the Council and senior executive boards. However, this didn't imply that the role of the USSR in legal regulation of local governments would increase.

After adoption of the Constitution of the USSR in 1936, all republics were involved in working our new constitutions until March 1937. The period from March 1937 to January 1938 was highlighted by adoption of constitutions in autonomous republics that were enacted by the Supreme Councils of republics. 
The situation with centralization of competences of local governments remained almost unchanged, for the volume of these competences was redistributed across levels of power from time to time. This situation in the USSR and the RSFSR as its part didn't change until adoption of the new Constitution of the USSR and then the Constitution of RSFSR.

The Constitution of USSR from October $7^{\text {th }}, 1977$ contained norms on organization of local government. Thus, its Preamble pointed out preservation of ideas and principles of the Constitutions of 1918 and 1936. Therefore many rights of the USSR stipulated by the Constitution of 1936 were preserved and even extended. According to Soviet scholars, the principle difference of this new Constitution from the previous ones lay in the fact that it contained an open list of competences [9].

To follow provisions of the Constitution of 1977, the new Constitution of RSFSR of 1978 established almost the same rules concerning its status as a part of the USSR and competences in regulating local governments. This shows its subordinate character to the USSR. However, this subordination was determined by distribution of powers that was not so important and clear. It seems that law makers didn't see any need in establishing constitutional norms concerning distribution of competences between the USSR and its republics.

The same situation was with the Constitution of RSFSR of 1978 that copied norms of the mentioned USSR Constitution relevant competences of autonomous republics. Limits of these competences remained absolutely unclear, because, the same as the USSR Constitution, the Russian Constitution enlisted competences of the RSFSR

This referred to the fact that the RSFSR was still on its way to become a federation. This could be explained by the fact that the ideology of the Soviet federalism was based on centralization of the most important political powers.

Period from 1979 to 1985 was marked by stagnation and crisis of the Soviet state system. It could be difficult to organize properly local government agencies when legal regulation was going through serious changes.

At the end of the 80s the Soviet authorities intended to give a new impulse to development of local government agencies. However, changes that took place in political life made it quite complicated a task. Therefore in April $9^{\text {th }}, 1990$ there was adopted a law concerning "The General Principles of Organization of Local Government and Local Economy of the USSR", which determined new tendencies in developing local government agencies, principles of their formation and functioning as local governments, as well as self-organization of local population. According to Article 7 of the aforesaid Law, local government agencies were subject to the Constitution of the USSR, constitutions of the Soviet and autonomous republics, laws of the USSR, Soviet and autonomous republics.

Meanwhile, this Law didn't constitute clear division of competences among the USSR, Soviet and autonomous republics in regulating local government. The problem remained even after adoption of the Law "About Local Government of the Russian Federation" from July $6^{\text {th }}, 1991$. Moreover, among the existing federal subjects only republics had a right to make local legal acts concerning local government issues, i.e. laws concerning local government, local referendum, elections in local Councils.

Local government agencies and administrations of provinces, regions, autonomous regions and autonomous areas were to foster development of the system of local government. However, they could not make decisions regulating local government agencies.

Adoption of the Constitution of the Russian Federation in 1993 highlighted a new stage of development of competences of federal subjects in the Russian Federation. It gave birth to a new model of relations between the Russian Federation and its federal subjects. Article 71 of the Constitution codified matters of authority, while Article 72 entrenched matters of joint authority of the Russian Federation and its subjects. Likewise, fundamentals of organization of local government underwent changes. According to Article 72, sub-section " $n$ ", codification of general principles of organization of the system of agencies of state power and local government are subjects to joint competence of the Russian Federation and its subjects.

A federal law concerning local government started developing in 1994. In compliance with a plan of priority measures on realization of the first President's Message to the Federal Assembly, the government of the Russian Federation prepared a draft federal law concerning general principles of organization of local government. In December 1994 it was introduced to the State Duma.

The Law concerning "General Principles of the Organization of Local Government in the Russian Federation" contained provisions of all three versions of the project. This Law became a type of compromise, though it was based on one of the deputy's projects.

In August $28^{\text {th }}, 1995$ the Law was signed by the President of the Russian Federation; in September $1^{\text {st }}$, 1995, after being published, it came into legal force. Thus, the Law highlighted a new stage in developing legal basis of local government.

Recently great efforts have been taken to find ways of dividing competences between Russia and its federal subjects in various fields of social life including local government. In 2001 and 2002, the Presidential Committee created 
by a presidential decree prepared quotations for dividing competences among federal agencies of state power, state power agencies of the federal subjects and local government agencies. These efforts culminated in adoption of a new Federal Law concerning "General Principles of the Organization of Local Government of the Russian Federation" in October $6^{\text {th }}, 2003$.

However, the analysis of genesis of competences of the Russian federal subjects in managing local government allows us to make the following conclusion.

Competences of federal subjects in a state where federalism makes a principle of state structure can be subject to a cyclic historical process. Centralization and decentralization of competences in governing local agencies can regularly alternate with one another. Regular change of these periods doesn't imply that this federation is unsustainable or unstable.

Development of such a complex institute as local government presupposes systematic reconsideration of proportions determining scope of rights regulating local government [10].

It is no easy matter to find the right balance in defining the scope of rights concerning local authorities. This can be explained by the fact of dynamic development of society and state. Therefore it is difficult to avoid shifting from centralization to decentralization of competences in regulating local government in a federative state. It is essential that periods of such changes should not result in critical forms of concentration or deconcentration of government agencies.

\section{References}

Pejanovic, Mirko. Local Self-Government: A Must for Democracy, Civil Society and EU Integration. Reference: 18. 07. 2014. URL: http://www.berghof-conflictresearch.org/documents/publications/daytone_pejanovic_civilsoc.pdf

Local US Governments. Reference: 21.07.2014. http://www.nlc.org/build-skills-and-networks/resources/cities-101/city-structures/localus- governments

Isaev, I. A. History of the Russian State and Law: Complete course of Lectures, 2nd edition. Moscow, Yurist. 1994.

Mukharev, R. M. Political Science. 2nd edition. Moscow, "Prior" Publishers. 2003. P. 432

Topornin, B. N. Constitution of the Russian Federation. Commentary. Edited by B. N. Topornin, Y. M. Baturin, R. G. Orekhov. Moscow, "Uridicheskaya Literatura" Publishers. 1994. P. 28-31, etc.

European Charter of Local Self-Government Strasbourg, 15.X.1985. Reference: 20.07.2014. URL: http://www.osce.org/ kosovo/38288?download=true

Constitution of RSFSR from July 10th, 1918 . Articles 53-57 // Constitutions and constitutional acts in 1918-1937. Moscow, 1940. P. 2728.

Convention on the Participation of Foreigners in Public Life at Local Level Strasbourg, 5.II.1992 Reference: 15.07.2014. http://conventions.coe.int/Treaty/en/Treaties/Html/144.htm

Nation Building and Law in the Soviet Union. G. V. Atamanchuk, V. I. Vasiliev, S. E. Zhilensky. Editorial staff: D. A. Kerimov, etc. $2^{\text {nd }}$ edition. Moscow: Mysl, 1986. P. 144.

Silvestri, John H. and Mark S. Nelson, McQuillin Municipal Corporation, Third rev. ed. The Law of Municipal Corporations. 1(1.01-3A.26), 1999. 